Iberian Journal of the History of Economic Thought

ISSN-e: 2386-5768

https://dx.doi.org/10.5209/ijhe.72625

\title{
Liberal politician, interventionist policymaker: Oswaldo Aranha's Economic Thought
}

Ivan Colangelo Salomão ${ }^{1}$

Recibido: 15/11/2020 / Aceptado: 27/02/2021

\begin{abstract}
Oswaldo Aranha was one of the most famous and prestigious Brazilian politicians of the $20^{\text {th }}$ century. Known for presiding the UN session when the State of Israel was created, Aranha had an important role in Brazilian politics during the first half of the century. Even though he held a bachelor's degree in Law, Aranha had to deal with various economic issues along his political career. This paper aims to analyze his economic ideas, arguing that despite his liberal influences, he became an interventionist policymaker in Getúlio Vargas's administrations. We argue that his experience as the Brazilian Ambassador in Washington played a central role in the changes of his ideological positions and economic ideas.
\end{abstract}

Keywords: Brazilian Economy; Oswaldo Aranha; Liberalism; Developmental State

JEL Codes: B29; B31; N96

[es] Político liberal, elaborador de políticas intervencionistas: el pensamiento económico de Oswaldo Aranha

Resumen: Oswaldo Aranha fue uno de los políticos brasileños más importantes y prestigiosos del siglo XX. Conocido por presidir la sesión de la ONU cuando se creó el Estado de Israel, Aranha tuvo un papel aún más relevante en la política brasileña durante la primera mitad del siglo. Aunque licenciado en Derecho, Aranha tuvo que lidiar con diferentes problemas económicos a lo largo de su carrera política. El propósito de este artículo es analizar sus ideas económicas, argumentando que, a pesar de sus influencias liberales, Aranha se convirtió en un formulador de políticas intervencionistas durante los mandatos de Getúlio Vargas. Argumentamos que su experiencia como embajador brasileño en Washington tuvo un papel central en las mudanzas de sus posiciones ideológicas y sus ideas económicas. Palabras clave: Economía brasileña; Oswaldo Aranha; Liberalismo; Estado desarrollista

Códigos JEL: B29; B31; N96

Sumario: 1. Introduction. 2. Oswaldo Aranha's economic thought. 2.1. Liberalism in Aranha. 2.2. State intervention. 3. Oswaldo Aranha as Minister of Finance. 3.1. Vargas' first administration (1930-1945). 3.2. Vargas' second administration (1951-1954). 4. Concluding remarks. References

Cómo citar: Colangelo Salomão. I. (2021): “Liberal politician, interventionist policymaker: Oswaldo Aranha's Economic Thought” en Iberian Journal of the History of Economic Thought 8(1), 1-11.

\section{Introduction}

Known for his prolific international career, Oswaldo Aranha is considered the most important Brazilian diplomat since José Maria Paranhos (Ricupero, 2017). Famed for the opportunity of chairing the United Nations General Assembly, Aranha gained the prestige of the foreign establishment like no other Brazilian of his generation.

Even though the deference to his diplomatic career could be justified for the prestige he gained in international arenas, Brazilian historiography might underestimate the other virtues of the young politician who led the 1930 Revolution and became one of the most relevant public men in his country in the first half of the $20^{\text {th }}$ century. Minister of several portfolios throughout the Vargas Era (1930-1945; 19511954), Aranha was considered the second man in the hierarchy of the Republic, position from which he contributed to the current formatting of Brazilian institutions, in its positive and negative aspects, during the two decades in which Getúlio Vargas ruled the country.

Despite the abundance of predicates that historians use to qualify his career, his economic ideas are not properly known ${ }^{2}$. Although he had studied economic issues only at the Faculty of Law, Aranha had to deal with various economic topics along his political career. Born in 1894 in Alegrete, a small city close to the border with Argentina, Oswaldo

\footnotetext{
Federal University of Paraná (Brazil)

E-mail: ivansalomao@gmail.com

ORCID: https://orcid.org/0000-0001-5857-7505

2 Almeida's book (2017), whose scope refers to Aranha's economic thought, does not intend to critically analyze his ideas. It is just a propaganda pamphlet.
} 
Euclydes de Sousa Aranha was son of a traditional farmer from São Paulo who moved to the south after getting married to local woman. Educated at home by his mother, he went to a Jesuit school in São Leopoldo, a municipality close to the capital of the state of Rio Grande do Sul. Unlike most of his future partners who belonged to the so-called "Geração 1907"" -who had attended law schools in São Paulo or Porto Alegre (Love, 1975)-, Oswaldo moved to Rio de Janeiro at the age of 14. He graduated in Law in 1916.

In the capital of the Republic, Aranha realized he was closer to the Federalists than to the official party which his father was linked to -and which he would take up arms in the future, the Riograndense Republican Party (PRR)-. A declared admirer of the liberal Senator Rui Barbosa, the student leader protested Hermes da Fonseca's government, and fought against Senator José Pinheiro Machado, the main leader of his party in Rio de Janeiro. He also attended the university group known as "Gaspar Martins", a tribute to the top leader of the opposition to PRR in the $19^{\text {th }}$ century. Once graduated, he returned to the southern border to work as a lawyer in 1917, when he met Getúlio Vargas, who was also working in that area.

Despite his friendship with Joaquim Assis Brasil, leader of the Libertador Party and opponent of the Republicans in Rio Grande do Sul, Aranha's family supported, in 1922, the fifth reelection of Antonio Borges de Medeiros, leader of the PRR. Although he had never thought of abandoning his party, Oswaldo had to overcome his political-ideological convictions to maintain the compromise previously agreed with Medeiros.

In 1923, when the last of several conflicts in Rio Grande do Sul between chimangos (republicans) and maragatos (liberals) broke out, Aranha quit his lawyer career to lead one of the main platoons of official troops, the $5^{\text {th }}$ Corps of the West Brigade. In the following years, he kept fighting on the battlefield, when he was shot in the shoulder and, more seriously, in the foot.

In January 1924, Borges de Medeiros chose him to be the head of police in the border region; in the following year, he became mayor of Alegrete. Two years later, he was concomitantly elected to the state and federal deputies, position he held only for a few months ${ }^{3}$. When Vargas took over the state administration in 1928, he invited Aranha to be the Secretary of Interior and Justice, when he was in charge to write his first text on economic matters.

Despite the good relations he had with the politicians from São Paulo, Aranha articulated the formation of the Frente Única Gaúcha (Unique Gaucha
Front) and the Aliança Liberal (Liberal Alliance). After Júlio Prestes's victory in the 1930 election, he commanded the insurrection that would put an end to the period so-called "Old Republic". In charge of the political and military organization of the revolution, Aranha's leadership went beyond the borders of his state.

Thus, the real dimension of Aranha's role in the Revolution of 1930 must be reconsidered. Given Getúlio's conciliatory behavior, he would hardly have headed an armed action. With José Antônio Flores da Cunha and a few dozen soldiers, the combatant -who had threatened to resign his position in the government in protest to "the weakness of his leader that he discouraged the soldiers themselves" (apud Hilton, 1994, 49)- Aranha led the invasion of the Army Headquarters, in Porto Alegre, on the night of October 3, 1930. Three weeks later, Washington Luís was overthrown by the Armed Forces at the Catete Palace.

In Vargas' first government, Oswaldo Aranha assumed four different positions: Ministry of Justice (1930-1931) and Finance (1931-1934), the embassy in Washington (1934-1937) and the chancellery (1938-1944). His performance as a public policymaker between the revolution (1930) and the end of World War II (1945) will be analyzed from the second section of this article.

His liberal positions made him support Eduardo Gomes, from the National Democratic Union (UDN), in the 1945 national election. Even so, he was nominated by the elected president, Eurico Gaspar Dutra, to assume the leadership of the Brazilian delegation in the United Nations, in 1947. Due to a series of coincidences ${ }^{4}$, he presided the meeting in which the UN created the State of Israel.

Away from political activities since the late 1940s, Oswaldo started to dedicate himself to law and business representation activities. He returned to politics in 1953, when the severe political and economic crisis that Brazil was going through made Getúlio Vargas invite him to be the Minister of Finance again. During Kubitscheck's administration (1956-1961), he headed the Brazilian delegation at the $12^{\text {th }} \mathrm{UN}$ General Assembly, in 1957. From then on, he definitively abandoned his political career. Oswaldo Aranha died in 1960, in Rio de Janeiro, at the age of sixty-five years old, from a heart attack.

For all these reasons, it was expected that Oswaldo Aranha had become Getúlio Vargas' natural successor. However, the mistrust of the president did not allow Aranha to become a feasible candidate 5 . After 1954, his name was constantly considered to be nom-

Being a Congressman was not his favorite political activity: "I confess that I did not like it. I was a State Deputy one day, and I was a Federal Deputy, I believe for four or five months, and I did not feel a vocation for this, and for that reason I did not plead for these positions again" (apud Aita and Axt, 1999, 82).

4 In January 1947, Oswaldo Aranha visited the United States to take part in an event at the World Affairs Council, when, due to the death of the diplomat who had been appointed to head the Brazilian representation at the UN, President Dutra invited him to assume the position (Almeida and Araújo, 2013, 691).

President Vargas has always encouraged the rivalry between Aranha and the diplomat João Neves da Fontoura, another revolutionary leader. Thus, he could behave as a judge, diluting the strength of both. 
inated the candidate by Vargas' party (Brazilian Labor Party). Perhaps the minister himself recognized that, influential among politicians, he never gained the popular support that a leader of the nation necessarily needs. That is why Berson $(1971,35)$ declared that "Aranha would become a leader of the people; never a popular leader".

\section{Oswaldo Aranha's economic thought}

Despite the number of letters Oswaldo Aranha sent to his family members and supporters since adolescence, he did not write documents or articles that reflect his most important political or economic ideas. The natural speaker was not exactly a fruitful writer ${ }^{6}$, so official documents, such as reports and speeches, become important sources for the researcher who intends to study and interpret his ideas.

A first feature that would come to influence his political trajectory was the distance he maintained from positivism, the official ideology of the PRR that had been spread in Rio Grande do Sul by the party's patriarch, Júlio de Castilhos. Whether by paternal influence or by the fact he studied in Rio de Janeiro, Oswaldo can be considered the most liberal of the republican leaders from Rio Grande do Sul who took office in 1930 (Lago, 1996). His "original liberalism" did not prevent him to adopt intervention policies when he became Minister of Finance, though. According to Fonseca's definition (2015), there is not such a thing as a "liberal interventionism", so the matching of these two doctrines becomes possible only in specific historical situations.

Regarding specifically to his theoretical influences, it is known that, before moving to Washington, in 1934, Aranha had the 5 volumes of the work of the French economist Clément Colson, and Principles of Economics, by Alfred Marshall ${ }^{7}$. In the United States, Oswaldo got, among other books, a copy of the first edition of the General Theory of Employment, Interest and Money, by John Maynard Keynes ${ }^{8}$. Such doctrinal eclecticism would influence not only on his ideas, but also the policies adopted by Minister Oswaldo Aranha.

\subsection{Liberalism in Aranha}

Although he defined himself as a liberal in the Anglo-Saxon sense of the term, Aranha was, in political terms, a man of $20^{\text {th }}$ century. Thus, he remained equidistant from the poles that would characterize world geopolitics after the 1920s: "Brazil is threatened by two evils: mediocre fascism or empirical communism. To save it, there is only liberal democracy" (apud Flores, 1991, 45). Despite the moderation of his speeches, there were several opportunities when he could be considered a conservative politician": "I increasingly believe in the fruitful action of conservative ideas [...]" (Aranha, 1927). His anti-communist conviction ratifies this understanding, since he did not hesitate to ally himself with the integralist leader Plínio Salgado to fight what he called "sovietism".

From an economic point of view, the way he defended some Brazilian policymakers with conservative ideas reveals his preferences. Aranha referred to the former Minister of Finance as the "great and unequaled Joaquim Murtinho", "the greatest of all in this country", to whom he attributed the solution to the crisis of the first republican decade (Aranha, 1934a). To Eugenio Gudin, "master of our masters", whose advice he considered "superiorly wise and opportune" (Aranha, 1953c), Aranha sent a letter in which he declared his irrevocable creed in liberalism, saying "it is no longer necessary to believe in men or in governments" (apud Berson, 1971, 217).

The experience as an ambassador in the United States can be considered the turning point in Aranha's ideas. Regardless of New Deal policies, the time that Oswaldo lived in the US was one of the most rapid GDP growth in the first half of the century. He believed such progress was due to the traditional liberalism. In a letter sent to Vargas, he stated that "everything here is the work of freedom"; to Pedro Góes Monteiro, Minister of War, he testified that it was "without action by the governments, that these people created a nation that holds more than half of the universal wealth"10 (apud Hilton, 1994, 206). In 1947, at the head of the UN General Assembly, he defended, without worrying about the obvious exaggeration of his declaration, that the only solution for the

Despite his well-known cognitive ability, Oswaldo Aranha himself admitted that he had little aptitude for intellectual activities: "I have a more acute practical spirit than the theoretical... I am more of a man of action than of ideation" (apud Hilton, 1994, 3); "I was born more to act than to think and write" (apud Hilton, 1994, 9).

This is the only information his grandson, the economist Luiz Aranha Correa do Lago, knows about his grandfather's interests in economics. According to Lago, Aranha was not the kind of politician used to study economic and political problems by a theoretical point of view. Even though he confirms that Aranha has read at least part of the books he bought in the United States, Lago did not confirm how those authors influenced his political measures after becoming the most important minister in Vargas's administration.

The influence of the General Theory was clear when he took over the Ministry of Finance in 1953. Even though he defended orthodox measures, he admitted the convenience of countercyclical action as a way of mitigating the insufficiency of effective demand: "It cannot be denied that, to some extent, some imbalances and unevenness can constitute real stimuli for sectors where there is a relative delay, as it is certain that strong demand drives supply. This automatism, however, is severely impaired in inflationary situations, during which responses to demand stimulus take too long due to the rupture in the relationship between prices" (Aranha, 1953a).

9 Although analytical categories as "conservatism" should be nuanced by the historical circumstances, some Aranha's measures and statements could frame him as a conservative politician. He proposed, for instance, the suppression of alcoholic beverages, any type of gambling and prostitution in the beginning of his political career. In addition, it imposed restrictions for female participation in certain audiences unrelated to education or health (Berson, 1971, 60). According to the same author, Aranha also defended that immigrants moved in Brazil, if they were Arians: "We need in Brazil whites, whites and always whites, and nothing from other races - neither Indians, nor blacks, nor yellow" (apud Berson, 1971, 224).

10 Oswaldo Aranha stated, in 1936, that "American civilization stands out from the rest due to its material characteristics (...). The truth is that the 
world would be "its Americanization"11. In Berson's opinion (1971), the lessons learned from the North American reality were responsible for converting the ideas of a man who, recently, had supported the adoption of "Napoleonic measures" as an excellent means of organizing social activities.

Although too schematic, the defense of liberalism in Aranha can be summarized in the following cardinal points: (1) agrarian vocation; (2) free trade; (3) balanced budget; and (4) importance of private business.

At the beginning of the 1920s, as a young lawyer in Rio Grande do Sul, face to the crisis in agriculture, Aranha defended that these activities were more relevant to the development of the state than industrial ones. He suggested that it was necessary to put "a brake on the teeth of insatiable industrial commercialism" in order to "enter a serene path of construction and improvement, without high greedy dreams" (Aranha, 1922). When he took over the Ministry of Finance in 1931, he showed the same awareness about the importance of coffee for Brazilian economy:

The coffee issue is not from São Paulo; it is Brazilian and regards to everyone. It is not a political issue. It is a matter of administration and specialized technique. The president will decide to keep the Institute [of Coffee], expanding his action both in terms of maintaining prices and in terms of increasing exports. (apud Almeida, 2017, 573)

In a conference held at the Chamber of Commerce of the State of New York, he had defended Brazilian agrarian vocation by stimulating free trade with the United States: "(North American) capital to be invested in Brazil must target the sources of its natural wealth in order to make them exportable, allowing my country to buy its unique manufactures here from American industry" (Aranha, 1936a).

This was another feature of his liberal principles: the defense of international free trade. Aranha attacked the "assumption that national wealth is watertight, and that international trade is limited", a premise that would support the false idea that "the prosperity of one nation is only possible through the impoverishment of another" (Aranha, 1937). In the same speech, he also defended that, according to the rules of "good economy", it was necessary to "buy to sell and sell to buy, resisting economic nationalism".

Endorsing free trade, his statements corroborate the fruitfulness of foreign trade: "In a world of highly prosperous nations, each nation would gain advantage from the prosperity of the others", said the former chancellor in New York (Aranha, 1947b). Beyond geopolitical motivations, he repeatedly defend- ed that Brazil had to restore diplomatic relations with the Soviet Union based, fundamentally, on its trade potential (Cervo, 1998).

If he was not influenced by positivism during his formal education, Oswaldo Aranha agreed with the only liberal facet of Auguste Comte's doctrine: balanced budget. Since the experience at his hometown administration, Oswaldo opposed, in different circumstances, the policy of taking loans. The main reason was that the future burden for the public treasury would not only not compensate the indebtedness, but it would make "normal tax activities" even more difficult.

Before assuming the Ministry of Finance for the first time, in 1931, he again attested that "without a balanced budget, I will not be Minister of Finance", since "a country without the capacity to balance its budgets is like a ship that cannot resume its course" (apud Hilton, 1994, 118). At the same time, he wrote a letter to Borges de Medeiros criticizing certain states for incurring fiscal deficits, reminding he was the first Minister to end the year with balanced budget since the Campos Salles administration (1898-1902). In 1954, Aranha opposed the proposal of the Minister of Labor, João Goulart, to grant a nominal increase of $100 \%$ to the minimum wage, a measure he classified as "anarchy of the treasury" (apud O'Donnell, 1976, 83).

Finally, but no less important, it is relevant to reveal a position not common for a politician of the 1930s. Key issues to modern liberalism, such as efficiency and productivity in public services, were present in his speeches. For Aranha, public action could not be the final reason for the State to act. When he was mayor of his hometown, in 1925, he disapproved the possession of various equipment and public buildings and requested authorization to "make the sale of all that he deems harmful to our assets or unnecessary to public services" (Aranha, 1925). Almost thirty years later, he again ratified the same understanding when he defended the relevance of the business for the sustainability of economic growth: "The integrated and harmonious development will always be impeded if any disorderly growth of the private sectors occurs" (Aranha, 1953a).

Despite clear demonstrations of his belief in liberalism, Aranha's biography would have to compromise the interventionist policies that the minister would defend throughout his political trajectory.

\subsection{State intervention}

The referred theoretical eclecticism of Oswaldo Aranha's economic thought can be measured by his ability to endorse interventionist policies without abdicating, however, his liberal premises. The main

cultural progress of that country has reached an unparalleled degree of perfection, but it is no less true that it has not fallen from the sky, on the contrary, it is the product of the effort of a people that acquired the ability to create, produce and to build this greatness with their own ideas, with their own hands" (Aranha, 1936a).

11 "We Brazilians envisage just one solution for the world: its Americanization" (Aranha, 1947a). 
instruments of interventionism policies defended by Aranha can be summarized in: (1) state intervention; (2) industrialization; (3) protectionism; and (4) nationalism.

Although the intervention defended by positivists was not one of the main ideas he learned from Comte's doctrine, Aranha agreed with some positivist policies. As soon he was elected mayor of his hometown Alegrete, he promised to use the state prerogative to achieve the purposes of his administration: "It is necessary to have wills -teaches Comte- to complete the laws, to consolidate the order, to make progress" (Aranha, 1925).

In charge of Getúlio Vargas' program, he coordinated an economic panorama of the state, published, in 1929: "The trade in Rio Grande do Sul". The document listed various areas where the state intervention was not only necessary, but also required. Thus, he explained the crisis that the colonial cultures of Rio Grande do Sul went through with these words: "Adventurous empiricism, dispersive individualism, free disorderly competition". In the end, Aranha concluded: it was due to "lack of a collective discipline, of a higher orientation" (Aranha, 1929).

In April 1934, Aranha made, in a session of the National Constituent Assembly, his most incisive speech in defense of state intervention. There were several moments when the Minister of Finance moved away from liberalism to define what he characterized as "the modern state". In his point of view, "government action today is no longer that of the last century, when the vain and theoretical formulas that we are trying to imitate were erected". Furthermore, he announced that the "modern state, whatever the form of government, has left the orbit traced by our political past to extend its intervention on fields and activities until recently prohibited to the action of the public policymakers". Finally, speaking about the causes of the economic depression of the 1930s, he ended the speech concluding that "the peoples could no longer stand with their arms crossed the anachronism of individualist theories, of pseudo liberals, nor even the empire of immortal principles, when the human frame what has been reduced by these ideologies is the most bitter and sad in universal history". Thus, the crisis would have resulted, in his view, from the "exploitation of man by man, without the intervention and protection of the state" (apud Flores, 1991, 61).

Aranha acknowledges the importance of the market laws to guarantee the good functioning of the economy. Even so, he pleased the monetary policy as a means of instigating the 'animal spirit' of entrepreneurs: "The currency obeys its own laws, superior to our laws. The currency can, however, be the instrument of a policy. There are no currencies, but politics in our times, said a great professor of finance" (Ara- nha, 1953c). He also attributed to the public power the responsibility for investments, especially in infrastructure, when the private sector does not do it properly: "There are sectors in which the State has to act promptly and energetically, in order to remove obstacles and eliminate certain bottlenecks in the national economy" (Aranha, 1953a).

Although he was aware of the importance of the agriculture for the Brazilian economy, Oswaldo Aranha considered manufacturing a relevant sector for the economic development of the country. Quoting Ernst Wagemann ${ }^{12}$, a German economist known for the defense of the state intervention, Aranha believed in the "harmonic development" of Brazil, given that "when industry and agriculture are in a balanced situation, the country's economy is highly resistant against crises" (Aranha, 1936b).

In a letter addressed to President Getúlio Vargas, in the end of 1942, Aranha summarized what Brazil's economic strategy should be after the end of the world conflict: "Creation of an industrial park for heavy industries; creation of the war industry; creation of agricultural, extractive and light ore industries complementary to the Americans and necessary for world reconstruction; extension of railways and highways for economic and strategic purposes; exploration of essential fuels" (apud Almeida and Araújo, 2013, 704). There is a clear emphasis on what, at that moment, was the most appropriate plan: heavy industrialization, if it was associated with American capital.

Even though he has repeatedly declared himself a defender of free trade, Aranha endorsed protectionist trade policies more than once during Vargas Era. In 1934, he defended that "the so-called freedom of trade was not and is not, given the power of concentration and direction of capital, but a farce: an economy directed by particular interests associated to explore and to profit" (apud Flores, 1991, 62). In a letter addressed to Chancellor José Carlos de Macedo Soares, a central character in making feasible US investments in Brazil, Aranha accused the trade agreement with the United States - which, ironically, would be celebrated with joy by himself eight months later - to be detrimental to the most legitimate national interests, especially industrial development. In an unusual tone even for chauvinist politicians, he resorted to nationalist rhetoric to attack it: "We neither want nor can we accept indirect vassals" (apud O'Donnell, 1976, 84).

From a nationalist point of view, he defended the impossibility of the universalization of theories and the geographical transposition of historical experiences. Defending the state intervention, he suggested that it was "useless, for the solution of the universal problem, the adoption of normal rules and standards, however good and recommendable they may be,

\footnotetext{
12 According to Curi (2018), Wagemann was recognized for proposing countercyclical policies to combat the German economic crisis of the 1930s. The disruption of the Weimar Republic and the consequent rise of Nazism, however, prevented his ideas from becoming public policy.
} 
even if it were the Ten Commandments. An adjustment is needed within each country, by its own people, of its own internal problems". During the Great Depression, he believed that only national and nationalists' policies would overcome the international crisis: "May each nation find, within its own borders, the solution to their difficulties" (Aranha, 1937).

Anticipating the debate about the creation of the largest Brazilian company and symbol of an era (Petrobras), Oswaldo Aranha yet disapproved (in the 1930s) the participation of foreign capital in the exploitation of Brazilian oil: "The contract requires that it be truly nationalized capital, not accepting foreign complaints about it" (apud Hilton, 1994, 163). To justify his position, he alleged the imprudence of "giving the economic fortunes of a people to the predominance of trusts, monopolies and industrial supercapitalism" (Aranha, 1934b). Aranha kept the same beliefs two decades later, when he denied to foreign capital the possibility of carrying stock options in Petrobras: "My experience in the public life of our country does not allow me to agree to any concession to Brazilians and less to foreigners for the exploitation of national wealth" (apud O'Donnell, 1976, p. 83). Thus, he defended a Brazilian and stateowned company.

Although the elements presented in this paper could not explain all the reasons for the "turning point" of his economic ideas, we suggest that his experience in Washington as the Brazilian ambassador in the United States played a crucial role on his political and economic positions. First, Aranha was a young man after becoming Vargas's main political advisor and, some years later, the most important connection with the country that would support Brazilian industrialization and economic development. Therefore, his political and economic ideas were not completely defined before the 1930 Revolution.

The American ideological environment might also have had an important role, especially if we consider the rise of the Soviet Union as a global superpower along the 1930's. Besides, the main political reason why President Vargas nominated him to the most relevant diplomatic position required a specific geopolitical and ideological attitude. Regardless his former ideas, Aranha understood he and the Brazilian government had to adapt to the new global context that was arising after the Second World War.

\section{Oswaldo Aranha as Minister of Finance}

Although Oswaldo Aranha's diplomatic career is more notorious than his political activities, the two times he oversaw Brazilian economy were considered successful considering the challenges the country was facing. Simonsen (1996, 383), for example, corroborates this point of view by stating that the "double passages by the command of national finances is less important in his biography than the achievements in politics and diplomacy. But, if his life had been limited to what he did at the Ministry of Finance, Aranha would have already won a captive seat in the history of Brazil".

The main issues he dealt with in the first time he was in charge of the economy (1931-1934) were the crisis of the coffee crops and the consequent renegotiation of the foreign debt. In the second period (1953-1954), he proposed a severe fiscal adjustment and formulated a successful policy to mitigate the severe exchange restriction at that time.

Thus, we defend that Aranha kept most part of his liberal premises, although he had to accept some interventionist policies to control economic cycles: if in the 1930s the global economic collapse made necessary a countercyclical action of the state, the adjustment of the 1950s could be understood as a sine qua non condition for economic growth (Fonseca, 2010). Like one of his icons, Rui Barbosa in 1889, Oswaldo Aranha temporarily forgot his liberal convictions to behave as an interventionist policy maker.

\subsection{Vargas' first administration (1930-1945)}

The revolutionary government took office during the most severe economic crisis in the history of capitalism. The international depression directly affected Brazilian economy by at least two ways: the fall of demand for Brazilian products and the collapse of the financing sources of the external debt.

The first Minister of Finance of the new government, the banker from São Paulo José Maria Whitaker, tried to keep a conservative-orthodox economic policy, both from a fiscal point of view and in relation to external debt. The global recession, however, made the defense of coffee his task number one. The problems the coffee farmers had been facing since the late 1920s -which exports, from 1928, fell from 90 million pounds/year to less than 40 at the beginning of the following decade-, combined with political crisis, convinced Oswaldo Aranha to accept an exceptional intervention in the market.

As soon as he took office in December 1931, Aranha tried to change the economic policies that Whitaker had adopted. Despite his conservative discourse, since the minister himself said "contrary to government intervention in the country's commercial life to value products and maintain artificial industries" (apud Hilton, 1994, 119), Oswaldo adopted measures to support the coffee farmers, which maintained the level of domestic income.

The most well-known policy adopted in his administration was the purchase and destruction of millions of bags of coffee, a measure that he considered to be "unenforceable and against good economic sense" (apud Hilton, 1994, 119). 30\% of the production was stocked, the same amount was exported and the remaining $40 \%$ was burnt, the "sacrifice quota" (Abreu, 2010, 5). He was probably aware of the countercyclical effects of this measure to keep 
the level of the national income because his fiscal policy was clearly expansionist, which resulted in budget deficits throughout the period ${ }^{13}$. Some of the most relevant economic data during his first experi- ence as Minister of Finance confirm that the Keynesian measures, he took were not only appropriate, but necessary (Figure 1).

Figure 1. Exports, GDP growth, and Investments (1930-1935)

\begin{tabular}{cccc}
\hline Year & Exports & GDP growth & $\begin{array}{c}\text { Investments } \\
\text { (\% GDP) }\end{array}$ \\
\hline 1930 & 319,4 & $-2,1$ & 9,7 \\
1931 & 244,0 & $-3,3$ & 7,6 \\
1932 & 179,4 & 4,3 & 7,2 \\
1933 & 216,8 & 8,9 & 8,8 \\
1934 & 292,8 & 9,2 & 10,6 \\
1935 & 269,5 & 3,0 & 13,1 \\
\hline
\end{tabular}

Source: Ipeadata.

Despite the importance of coffee for the Brazilian economy, Aranha's main task was to deal with the long renegotiation of external debt, which lasted until 1943, when he had already come back from the Brazilian embassy in Washington. The fall of the exportations after 1929, plus the collapse of the international financial market resulted in the interruption of the payment of the external debt on several occasions during the 1930s.

American and British governments did not recommend a third funding loan, which would join several old debts into a new loan ${ }^{14}$. The report written by the British commissioner Otto Niemeyer, published in July 1931, suggested the simple adoption of an orthodox economic policy: balanced budget, currency stabilization and the creation of a Central Bank (Abreu, 1974, 15). When the English government abandoned the Gold Standard, in September 1931, the international crisis led the Brazilian government to declare the partial suspension of payment of its foreign debt in the same month.

From then on, there was no alternative for creditors but to renegotiate a new consolidation, which the future Minister Oswaldo Aranha opposed at first - document signed by himself at the beginning of 1932. The agreement required the full payment of the previous funding loans (1898 and 1914) and the offer of new bonds, with interest rate of $5 \%$ and maturity in 1934. The amortizations of those two loans were suspended, reducing the annual payment of debt service from 24 to 12 million pounds (Abreu, 2010, 5).

However, the benefits of the agreement did not allow the payment of trade debts. In 1934, the minister articulated a new agreement with the American government, known as the "Aranha scheme". The agreement classified all the external loans in eight categories in order of 'quality'; the better rated the loan, the greater the proportion of amortizations that would be paid. It was conditioned to the performance of the trade balance, around 9 million pounds a year, what Aranha classified as "a supreme effort to pay all that is possible to pay" (apud Hilton, 1994, 178).

Regarding this issue, the minister has always tried to involve his speeches in a nationalist rhetoric, claiming to deal with "the authoritarian and dominating impositions of those who, lords of the world money, at one point made a loan to Brazil" (Aranha, 1934b). In any case, diplomatic circumstances allowed him to give the negotiations a nationalist aura ${ }^{15}$. Referring to creditors as "always lords of our destinies" (Aranha, 1934a), Aranha adopted a more nationalist strategy to deal with the creditors ${ }^{16}$.

His stance reached a new level after 'New State' coup, in November 1937. Even though the situation of the balance of payments was under control, Vargas determined, against Aranha's will, the interruption

13 According to data presented by Abreu $(2014,84)$, fiscal deficits remained above $12 \%$ of aggregate spending between 1931 and 1933 ; after this period, the monetary base also grew again.

14 The impression that Sir Niemeyer had drawn from the two previous agreements was not the most encouraging: "The man who sinks three times in general drowns" (apud Abreu, 2001, 16). Years later, when the "Aranha mission” succeeds in 1939, the same Rothschild's representative suggested that, if Brazil did not honor his commitments, "he would be ignored, with disgust, like a deadbeat" by the London city (apud Abreu, 1975, 60).

15 The less bellicose strategy adopted by American negotiators reflected Roosevelt's good-neighborhood policy. England, in turn, increased the influence in Argentina as much as it became less important in Brazil, since the trade deficits in which the USA incurred here guaranteed it a distinctive place in Brazilian diplomacy. This unveiled dispute between the two main creditors led the British representative to affirm that the United States saw Brazil "as its own backyard", getting mad "when anyone else comes to play in it without being invited" (apud Abreu, 2001, 23).

16 Trying to acquire public opinion, Aranha announced that Brazil would pay nearly a third of its contractual debt for the four years following the agreement. It is possible to check the inaccuracy of his statement in the fact that the minister calculated interest and amortizations together, which was not exactly true: "Whether Brazil pays 90 million pounds over 4 years, we will receive the full coupon, that is, the discharge of 90 million, which represents, for the federal, state and municipal treasuries, an advantage of 57 million pounds that have not been paid" (Aranha, 1934a). There was a decrease in service indeed, from 24 to up to 9 million pounds in the period of the agreement, as well as a reduction in contractual interest rates and postponement of payment of amortizations. 
of the 1934 agreement. Also, the president reintroduced the foreign exchange monopoly and declared a moratorium of the foreign debt. Seeking to co-opt the support of the Armed Forces, the president justified his decision focusing on the import of military and railway material. The real motivation of default, however, has been didactically described by Abreu $(1975,87)$ : the government abandoned the strategy of "what the minimum that creditors will accept" to embrace the strategy of "what the maximum we can pay without limit imports".

The solution for the situation started to be clear after Roosevelt's invitation to Aranha to visit him at the White House in February 1939. The so-called "Aranha mission" marked the beginning of a new relationship between countries, considering that, beyond the external debt, Brazil could guarantee other positive results, including trade and investment issues $^{17}$. Regarding the debt negotiation, however, the benefits were below the expectations. After reestablishing the payment of the debt and the liberalization of the exchange rate policy, Aranha arranged a credit line with Eximbank of US\$ 19.2 million, less than half the amount initially required (Abreu, 2014, 94).

Despite the wide negative repercussion in Brazil, the chancellor sought to involve the mission in a nationalist aura when he returned to Rio de Janeiro: "The Brazilian people understood that they need to grow from themselves, with decision and even sacrifice, because otherwise Brazil would continue to be the rich man of the desert: to beg in his own greatness" (Aranha, 1939). Besides, he resorted to politically incorrect analogies to distinguish Brazil's situation from other third-world countries:

It was time to say that we were a people who had mastered their destiny; a great nation that had resolved to become greater; a force that wanted to cooperate with other American forces so that America was not an Africa in disguise, but the land chosen for the lives of free, strong, friendly, prosperous, and peaceful peoples. (Aranha, 1939)

Aranha's role in negotiating foreign debt can be considered relatively successful, given that, in the early 1930s, Brazil paid more than its trade balance allowed; from 1937, the situation was the opposite, because the government spent less resources to pay the debt than indicated by its presumed "capacity to pay". Therefore, political factors became fundamental, such as the eminent position of Brazilian negotiators.

Besides frustrating the approximation of part of the Brazilian Armed Forces to Nazi Germany on the eve of World War II, Aranha's nearness to the United States contributed to the Brazilian industrialization project. Aware that the development of the industry would only be possible if associated with foreign capital, Aranha declared that the "Vargas program of industrialization (...) should be carried out with increasing American support" (apud Hilton, 1994, 411). The highlight of this relationship occurred with the creation of National Steel Company (CSN), in Volta Redonda, whose negotiation was involved in the well-known Brazilian bargain that opposed German and American interests. Finally inaugurated in 1941, CSN was financed and built with resources from the United States.

Foreign investment was not the only factor responsible for the robust industrial growth observed in the 1930s, however. The Brazilian government, and in particular, Minister Oswaldo Aranha, adopted several protectionist instruments to make national manufacturing viable, such as the increase of specific taxes, regulation of the compulsory consumption of national raw materials and a ban on imports of equipment for certain industries that could be produced in Brazil.

In 1934, Aranha signed a tariff reform with a clear protectionist bias, whereby the specific aggregate tariff was increased by $15 \%$ and doubled the number of tariff items. The main mechanism of trade protection resulted, however, from the devaluation of the Brazilian currency (mil-réis), which overlapped the other measures to defend Brazilian production. According to Abreu $(2014,89)$, it was a clear industrial protection policy, otherwise "it would be difficult to explain the considerable increase in the industrial product that characterized the decade after 1933". Fonseca (2003, $15)$ agrees with this point of view, arguing that it is possible to "inquire to what extent the government was aware of the depth" of its protective policy; but the industrial growth observed from that moment on should not be delegated to "fortuitous act, the result of chance, disconnected from the new directions given to the economy".

Despite a speech given some weeks before, the signing of the trade agreement with the United States in 1935 was largely result of Aranha's efforts. The vehemence with which he initially opposed the treaty proved to be a rhetorical game to contribute to the approval of the 1934 Constitution. He later classified it as "an important event for the world economy" (apud Hilton, 1994, 224), as the agreement increased trade between countries by favoring the importation of more than 30 American products, while lowering or excluding the tariff for the main items exported by Brazil, such as coffee and cocoa. Even though Brazilian industrialists have opposed the treaty ${ }^{18}$, it is not

\footnotetext{
Under Aranha's coordination, the Brazilian delegation drew up two documents listing a series of proposals to be negotiated with North American peers (Brazil's Economic Equipment and Agricultural Cooperation). According to Corsi (2012, 244), however, the reports had important divergences between them, especially regarding to the role of the domestic market and national capital for the development of the country.

18 Although the agreement provided for the entry of capital goods exempt from tariff - a measure that could attract investments to Brazilian industry -, some industrialists, led by Roberto Simonsen and Euvaldo Lodi, opposed the agreement, because they feared competition in light manufacturing sectors. The opposition to the agreement was only overcame the following year, after intense American pressure based on the threat of the imposi-
} 
possible to state that there was an excessive liberalization to foreign manufactured goods, considering the tariff increase that occurred before the beginning of negotiations.

As argued along the section, it is possible to characterize Oswaldo Aranha's first experience at the Ministry of Finance as "highly interventionist and nationalist" (Simonsen, 1996, 384). His economic administration could be considered heterodox, which brought beneficial results for the country. Although his economic ideas have considerably changed in the following decades, Aranha would intervene in the economy once more during the 1950 s, when he took office for the second time. The minister had changed, the circumstances too.

\subsection{Vargas' second administration (1951-1954)}

Aranha returned to public administration when he took over amid the severe economic crisis of the early 1950s. Besides the inflationary acceleration, the external situation was, again, the main problem of the Brazilian economy. When he took over the Ministry of Finance in June 1953, Aranha was an experienced politician with more liberal ideas than in his first experience.

Oswaldo Aranha had decided to maintain the economic policy of his predecessor, the industrialist Horácio Lafer: conservative fiscal, monetary and credit policies ${ }^{19}$. At that time, he defended austerity as a means of containing the inflationary process: "Inflation in our country has been sporadically combated, through partial measures that are invalidated because the main loopholes of the inflationary wave remain generally open: government deficits (...) and the immoderate expansion of bank credit granted to private sectors" (Aranha, 1953a).

Thus, the "Aranha Plan" proposed a rigorous global adjustment, whose main proposals could be summarized in:

Energetically compress the global volume of government spending on goods and services; lower the annual pace at which public works are currently expanding; prudently contain the speed of the industrialization process; apply strict selective controls to imports in accordance with the investment policy and the balance of payments possibilities; defend the stability of the internal purchasing power of the cruise and its international parity, by the cessation of emissions (...) as well as by a sound credit policy. (Aranha, 1953a)
Months later, however, Aranha noticed that the goals initially stipulated would not be achieved. Fiscal and credit policies did not achieve the intended contraction, strengthening the inflationary process. The minister himself summed up the difficulty in promoting the adjustment: "The first six months of my administration did not produce the minimum results that I could expect... There were deficit and emission, reduction in the purchasing power of the currency, increase in the cost of living, general imbalance" (apud Hilton, 1994, 474). The nominal increase of $100 \%$ of the minimum wage, enacted in May 1954, further weakened the already fragile fiscal situation. Oswaldo opposed the measure, proposing a readjustment of $33 \%$. The intensification of the political crisis, however, no longer allowed the government to take "half-measures".

On the international front, the currency crisis was no less severe. The deterioration of the external scenario, with the outbreak of the Korean War (1950-1953) and the election of Republican president Dwight Eisenhower in the United States - less friendly to the 'good neighborhood' policy in Latin America. As result, the second part of an Eximbank loan (US\$ 60 million) was cancelled. Besides, problems in coffee exports forced the Brazilian government to adjust its balance of payments in a very strict way.

In October 1953, the government enacted its boldest measure, the Instruction 70 of the Superintendence of Currency and Credit (SUMOC) ${ }^{20}$. The exchange rate liberal policy did not achieve its goals -"effects were contrary to the purposes most sought by the law, of attracting foreign capital and stimulating exports" (Aranha, 1953b)-, the minister created a mechanism for stabilizing and devaluing exchange rates, mitigating, however, its expected deleterious effects. The fixed exchange rate was maintained, but in practice, it was institutionalized the multiple rate system: two categories for exports (coffee and other products) and five for imports, according to its essentiality for the Import substitution industrialization (ISI). Thus, imports would be subsidized the more indispensable they were for the ISI, so that the more "essential", the lower the premium above the official rate to be paid in the auction. For exports, a bonus would be paid on the official exchange rate, making the rates more attractive to the exporter than those practiced on the free market.

In the short term, the results were favorable since the government managed to mitigate the deleterious effects of the currency crisis. In 1953, the trade balance had a positive result, contributing for the slight surplus of the balance of payments. Inflation, howev-

tion of a tariff on Brazilian coffee.

19 Apparently, it was due to an Aranha's advice that Minister Horacio Lafer adopted the so-called 'Campos Salles-Rodrigues Alves formula'. According to what had been carried out by these two presidents during the 'Old Republic' (1894-1930), economic policy would be divided into two steps: first, stability would be prioritized, focusing efforts on fiscal adjustment, and combating inflation. Once these imbalances are resolved, the government would then be able to stimulate the expansion of aggregate demand and, ultimately, sustained economic development.

20 At that moment, politically and intellectually more mature, Aranha started to quote liberal economists to ratify the prudence of his measure. Quoting Gottfried von Haberler, an Austrian School economist, the minister tried to confer an orthodox approval to his policies. Eugênio Gudin himself had already endorsed the plausibility of the measure in his Principles of Monetary Economics (1943). 
er, accelerated to $20 \%$ at the end of that year. Facing such important challenges, the political crisis did not contribute for the success of Aranha's measures. Some days before President Vargas' suicide, Aranha also sought to change the exchange rate system for export bonuses, an attempt that would result in a small increase in coffee sales in subsequent days, only.

At that moment, any effort would be harmless, however. The shot at Catete Palace shorten his second term at the Ministry, as well as his own political career by interrupting the life of the president who, in fact, made history.

\section{Concluding remarks}

Oswaldo Aranha's achievements in the international arena may justify the importance given to his diplomatic career. Still, his foray into the economic field should not be diminished. Lawyer with no formal training in economic issues, the minister responsible for planning the accelerated industrialization of the 1930s directly influenced the development of the Brazilian economy during Getúlio Vargas's terms.

Aranha's liberal convictions were useful in his experiences at the Ministry of Finance; the interventionist lessons learned from the political daily life, besides being useful, were also functional. The defense of coffee, whose exports were the dynamic center of the national economy, demanded the direct action of the State. According to the classical Celso Furtado's explanation (1982), countercyclical action helped the country not only to overcome the crisis earlier than most of the developed countries, but also managed to encourage the industrial sector as never seen before in Brazilian history.

During the renegotiation of foreign debt, the collapse of international financing resulted in no other alternative but to control imports and reschedule the debt. Diplomat by vocation, Aranha (and, later, Artur Souza Costa, Minister of Finance who succeeded him) delivered, in 1943, a much more comfortable situation in terms of its financial commitments, even though the cost of a clear submission to American diplomacy interests.

In the 1950s, in addition to the obvious currency devaluation required by the circumstances, the exchange auction system brought a temporary relief to external accounts. The deterioration of the political situation, plus the difficulties in attracting dollars, made his second administration at the head of the Treasury not to have the proper importance in the literature.

Thus, according to Simonsen's (1996) observation, it was not (only) Oswaldo Aranha's ideas that had been transformed; the problem to be faced had also changed. Therefore, a politician who professed liberal dogmas choosing interventionists policies was not exactly a contradiction; it demonstrates his ability to learn and to act in a multifaceted reality.

\section{References}

Abreu M. de P. (1974). A missão Niemeyer. Revista de Administração de Empresas, 14:4.

- (1975). A dívida externa pública do Brasil, 1931-1943. Pesquisa e Planejamento Econômico, 5:1.

- (2001). Brasil, 1824-1957: bom ou mau pagador? Working Paper, n. 237, Pontifical Catholic University of Rio de Janeiro, Department of Economics.

- (2010). A economia brasileira 1930-1964. Working Paper, n. 585, Pontifical Catholic University of Rio de Janeiro, Department of Economics.

- (2014). Crise, crescimento e modernização autoritária, 1930-1945. In M. de P. Abreu (Ed.), A ordem do progresso. Dois séculos de política econômica no Brasil. Elsevier: Rio de Janeiro.

Aita C. and Axt G. (1999). Perfil biográfico. In C. Aita, \& G. Axt (Eds.), Parlamentares gaúchos. Legislative Assembly of Rio Grande do Sul: Porto Alegre.

Almeida P.R. (2017). Introdução. O estadista econômico. In S.M. Lima, P.R. de Almeida, \& R.S. Farias (Eds.), Oswaldo Aranha: um estadista brasileiro. FUNAG: Brasília.

Almeida P.R. de, \& Araújo J.H. (2013). Oswaldo Aranha: na continuidade do estadismo de Rio Branco. In J.V. Pimentel (Ed.), Pensamento Diplomático Brasileiro. Formuladores e Agentes da Politica Externa (1750-1964). FUNAG: Brasília.

Aranha O.E. de S. (1999 [1922]). A Defesa da Indústria Pastoril. In C. Aita, \& G. Axt (Eds.), Parlamentares gaúchos. Legislative Assembly of Rio Grande do Sul: Porto Alegre.

- (1999 [1925]). Discurso de posse na Intendência Municipal do Alegrete. In C. Aita, \& G. Axt (Eds.), Parlamentares gaúchos. Legislative Assembly of Rio Grande do Sul: Porto Alegre.

— (1999 [1927]). Discurso proferido no Jóquei Clube do Rio de Janeiro. In C. Aita, \& G. Axt (Eds.), Parlamentares gaúchos. Legislative Assembly of Rio Grande do Sul: Porto Alegre.

— (1999 [1929]). O Sindicalismo no Rio Grande do Sul. In C. Aita, \& G. Axt (Eds.), Parlamentares gaúchos. Legislative Assembly of Rio Grande do Sul: Porto Alegre.

— (2017 [1934a]). Renegociação da dívida externa. In S. M. Lima, P. R. de Almeida, \& R. S. Farias (Eds.), Oswaldo Aranha: um estadista brasileiro. FUNAG: Brasília. 
— (2017 [1934b]). Nacionalismo econômico na Constituinte. In S. M. Lima, P.R. de Almeida, \& R. S. Farias (Eds.), Oswaldo Aranha: um estadista brasileiro. FUNAG: Brasília.

— (2017 [1936a]). Um elogio à civilização americana. In S. M. Lima, P. R. de Almeida, \& R. S. Farias (Eds.), Oswaldo Aranha: um estadista brasileiro. FUNAG: Brasília.

— (2017 [1936b]). Comparando as economias do Brasil e dos Estados Unidos. In S. M. Lima, P. R. de Almeida, \& R. S. Farias (Eds.), Oswaldo Aranha: um estadista brasileiro. FUNAG: Brasília.

— (2017 [1937]). Soluções nacionais para os problemas de cada país. In S. M. Lima, P. R. de Almeida, \& R. S. Farias (Eds.), Oswaldo Aranha: um estadista brasileiro. FUNAG: Brasília.

— (2017 [1939]). Retorno da Missão aos Estados Unidos. In S. M. Lima, P.R. de Almeida, \& R.S. Farias (Eds.), Oswaldo Aranha: um estadista brasileiro. FUNAG: Brasília.

— (2017 [1947a]). A profile of Brazil. In S. M. Lima, P. R. de Almeida, \& R. S. Farias (Eds.), Oswaldo Aranha: um estadista brasileiro. FUNAG: Brasília.

— (2017 [1947b]). The rise of interdependence. In S. M. Lima, P. R. de Almeida, \& R.S. Farias (Eds.), Oswaldo Aranha: um estadista brasileiro. FUNAG: Brasília.

- (2017 [1953a]). A situação financeira e econômica do país. In S. M. Lima, P. R. de Almeida, \& R. S. Farias (Eds.), Oswaldo Aranha: um estadista brasileiro. FUNAG: Brasília.

— (2017 [1953b]). O parlamento e as finanças. In S.M. Lima, P.R. de Almeida, \& R.S. Farias (Eds.), Oswaldo Aranha: um estadista brasileiro. FUNAG: Brasília.

- (2017 [1953c]). Os fundamentos do Plano Aranha. In S. M. Lima, P.R. de Almeida, \& R.S. Farias (Eds.), Oswaldo Aranha: um estadista brasileiro. FUNAG: Brasília.

Berson T.M. (1971) A political biography of dr. Oswaldo Aranha of Brazil, 1930-1937. New York University Press: New York.

Cervo A.L. (1998). Eixos conceituais da política exterior do Brasil. Revista Brasileira de Política Internacional, 41.

Corsi F.L. (2012). O projeto de desenvolvimento de Vargas, a Missão Oswaldo Aranha e os rumos da economia brasileira. In P.P.Z. Bastos and P. C. D. Fonseca (Eds.), A Era Vargas. Desenvolvimentismo, economia e sociedade. Edunesp: São Paulo.

Curi L.F.B. (2018). Nationalökonomie nos trópicos: pensamento econômico alemão no Brasil (1889-1945). Unpublished doctoral dissertation, University of São Paulo, São Paulo.

Flores M. (1991). Osvaldo Aranha. Instituto Estadual do Livro: Porto Alegre.

Fonseca P.C.D. (2003). Sobre a Intencionalidade da Política Industrializante do Brasil na Década de 1930. Revista de Economia Política, 23:1 (89).

- (2010). Nem Ortodoxia nem Populismo: o Segundo Governo Vargas e a Economia Brasileira. Tempo, 14.

- (2015). Desenvolvimentismo: a construção do conceito. In A.B. Calixtre, A.M. Biancarelli, \& M.A.M. Cintra (Eds.), Presente e futuro do desenvolvimento brasileiro. Brasília, IPEA.

Furtado C.M. (1982). Formação Econômica do Brasil. Nacional: São Paulo.

Hilton S. (1994). Oswaldo Aranha. Uma biografia. Objetiva: Rio de Janeiro.

Lago L.A.C. (1996). Oswaldo Aranha. O Rio Grande e a Revolução de 1930. Um político gaúcho na República Velha. Nova Fronteira: Rio de Janeiro.

Love J.L. (1975). O regionalismo gaúcho e as origens da revolução de 1930. Perspectiva: São Paulo.

O’Donnell F.T. (1976). Oswaldo Aranha. Garatuja/Instituto Estadual do Livro: Porto Alegre.

Ricupero R. (2017). Apresentação. In S. M. Lima, P. R. de Almeida, \& R. S. Farias (Eds.) Oswaldo Aranha: um estadista brasileiro. FUNAG: Brasília.

Simonsen M.H. (1996). Oswaldo Aranha e o Ministério da Fazenda. In A. Camargo, J.H.P. Araújo, \& M.H. Simonsen (Eds.), Oswaldo Aranha. A Estrela da Revolução. Mandarim: São Paulo. 